\title{
Quantitative Analysis of Polycyclic Aromatic Hydrocarbons (PAHs) Cited by the United States Food and Drug Administration *
}

\author{
by \\ William Guthery and Michael J. Taylor \\ Filtrona, Filtrona Technology Centre, Tyne and Wear NE32 3UP, UK
}

\section{SUMMARY}

The yields of 16 polycyclic aromatic hydrocarbons (PAHs) were determined from cigarette mainstream smoke condensate extracts using Gas ChromatographyTandem Mass Spectrometry (GC-MS/MS). The method has been validated for ISO and Health Canada Intense (HCI) smoking protocols. Quantifiable levels (ISO means 0.16 to $365 \mathrm{ng} / \mathrm{cig}$; HCI means 0.33 to $1595 \mathrm{ng} / \mathrm{cig}$; $\mathrm{n}=30$ ) of 15 PAHs were found in the Kentucky reference cigarette K3R4F. The coefficient of variance $(\mathrm{CV})$ was derived from ten determinations each run in triplicate. The CV range was $8.7 \%$ to $24.8 \%$ (ISO) and $6.6 \%$ to $24.3 \%$ (HCI). The limit of detection (LOD) based on empirical precision was $\leq 0.06 \mathrm{ng} / \mathrm{cig}$ (ISO) and $\leq 0.20 \mathrm{ng} / \mathrm{cig}$ (HCI) for all components except naphthalene (2.89 and $9.62 \mathrm{ng} / \mathrm{cig}$, respectively). The yields from 5 unspecified branded cigarettes (Samples A-E) and 2 other reference cigarettes, K1R5F and the CORESTA monitor CM7, were determined under ISO smoking conditions. The same 15 PAHs were detected as in the K3R4F; however, cigarettes with lower yields of total particulate matter (TPM) were found to contain significantly less PAHs. One component was measured below the limit of quantification (LOQ) in Sample E and 2 components were < LOQ in the K1R5F. [Beitr. Tabakforsch. Int. 25 (2013) 607-616]

\section{ZUSAMMENFASSUNG}

Die Ausbeuten von 16 polycyclischen aromatischen Kohlenwasserstoffen (PAK) wurden mittels Gaschromatographie/Tandem-Massenspektrometrie (GC-MS/MS) an
Extrakten vom Hauptstromrauchkondensat von Zigaretten bestimmt. Die Methode wurde nach den Rauchprotokollen von der ISO und Health Canada Intense (HCI) validiert. In der Kentucky-Referenzzigarette K3R4F wurden quantifizierbare Konzentrationen (nach ISO 0,16 bis $365 \mathrm{ng} /$ Zigarette; nach HCI 0,33 bis $1595 \mathrm{ng} /$ Zigarette; $\mathrm{n}=30$ ) von 15 PAK festgestellt. Der Variationskoeffizient (CV) wurde durch zehn Bestimmungen, jeweils dreifach durchgeführt, ermittelt. Der Bereich des CV betrug $8,7 \%$ bis $24,8 \%$ (ISO) bzw. $6,6 \%$ bis $24,3 \%$ (HCI). Die Nachweisgrenze basierend auf empirischer Genauigkeit betrug $\leq 0,06 \mathrm{ng} /$ Zigarette (ISO) bzw. $\leq 0,20 \mathrm{ng} /$ Zigarette (HCI) für alle Bestandteile mit Ausnahme von Naphthalen (2,89 bzw. 9,62 ng/ Zigarette). Die Ausbeuten von 5 nicht spezifizierten Markenzigaretten (Proben A-E) und 2 weiteren Referenzzigaretten, K1R5F und der CORESTA Monitor CM7, wurden unter ISO-Rauchbedingungen bestimmt. Es wurden dieselben 15 PAK wie in der K3R4F festgestellt, jedoch enthielten Zigaretten mit geringeren Ausbeuten an Gesamtpartikelmasse (TPM) signifikant weniger PAK. Ein Bestandteil in Probe E und 2 Bestandteile in der K1R5F lagen unterhalb der Bestimmungsgrenze (LOQ). [Beitr. Tabakforsch. Int. 25 (2013) 607-616]

\section{RESUME}

Les rendements de 16 hydrocarbures aromatiques polycycliques (HAP) ont été déterminés à partir d'extraits de condensés du flux de fumée principal de cigarettes en utilisant la chromatographie en phase gazeuse-spectrométrie de masse en tandem (GC-MS/MS). La méthode a été validée pour les protocoles de fumage de la norme ISO et de Health 
Canada Intense (HCI). Des niveaux quantifiables (soit pour ISO 0,16 à $365 \mathrm{ng} / \mathrm{cig}$ et pour HCI 0,33 à $1595 \mathrm{ng} / \mathrm{c}-$ ig; $\mathrm{n}=30$ ) de 15 HAP ont été trouvés dans la cigarette de référence K3R4F de type Kentucky. Le coefficient de variation $(\mathrm{CV})$ a été dérivé de dix déterminations, chacune effectuée en triple exemplaire. L'intervalle du CV était de $8,7 \%$ à $24,8 \%$ (ISO) et de $6,6 \%$ à $24,3 \%$ (HCI). La limite de détection basée sur une précision empirique était $\leq 0,06 \mathrm{ng} / \mathrm{cig}$ (ISO) et $\leq 0,20 \mathrm{ng} / \mathrm{cig}$ (HCI) pour tous les composants, à l'exception du naphtalène (respectivement 2,89 et 9,62 $\mathrm{ng} / \mathrm{cig}$ ). Les rendements de 5 cigarettes de marques non spécifiées (échantillons A-E) et de 2 autres cigarettes de référence, K1R5F et CORESTA monitor CM7, ont été déterminés dans les conditions de fumage de la norme ISO. Les 15 HAP détectés étaient les mêmes que dans la cigarette K3R4F; cependant, des cigarettes avec des rendements plus faibles de particules en suspension totales (PST) se sont avérées contenir beaucoup moins de HAP. Un composant était inférieur au seuil de quantification (SDQ) dans l'échantillon E et 2 composants étaient $<$ SDQ dans l'échantillon K1R5F. [Beitr. Tabakforsch. Int. 25 (2013) 607-616]

\section{LIST OF ABBREVIATIONS}

$\begin{array}{ll}\text { 5-MC } & \text { 5-Methylchrysene } \\ \mathrm{B}[a] \mathrm{A} & \text { Benz }[a] \text { anthracene } \\ \mathrm{B}[a] \mathrm{P} & \text { Benzo }[a] \text { pyrene } \\ \mathrm{B}[c] \mathrm{P} & \text { Benzo }[c] \text { phenanthrene } \\ \mathrm{B}[b] \mathrm{F} & \text { Benzo }[b] \text { fluoranthene } \\ \mathrm{B}[k] \mathrm{F} & \text { Benzo }[k] \text { fluoranthene } \\ \mathrm{B}[j] \mathrm{A} & \text { Benz }[j] \text { aceanthrylene } \\ \mathrm{C}[c d] \mathrm{P} & \text { Cyclopenta }[c, d] \text { pyrene }\end{array}$

CORESTA Cooperation Centre for Scientific Research Relative to Tobacco

CV Coefficient of Variance

$\mathrm{dB}[a h] \mathrm{A} \quad$ Dibenz $[a, h]$ anthracene

$\mathrm{dB}[a l] \mathrm{P} \quad$ Dibenzo $[a, l]$ pyrene

$\mathrm{dB}[a e] \mathrm{P} \quad$ Dibenzo[a,e]pyrene

$\mathrm{dB}[a i] \mathrm{P} \quad$ Dibenzo[a,i]pyrene

$\mathrm{dB}[a h] \mathrm{P} \quad$ Dibenzo $[a, h]$ pyrene

FDA Food and Drug Administration

GC-MS Gas Chromatography-Mass Spectrometry

GC-MS/MS Gas Chromatography-Tandem Mass Spectrometry

$\mathrm{I}[c d] \mathrm{P} \quad$ Indeno $[1,2,3-c d]$ pyrene

ISO International Organisation for Standardisation

ISTD Internal Standard

HCI Health Canada Intense

HPHC Harmful and Potentially Harmful Constituents

LOD Limit of Detection

LOQ Limit of Quantification

MRM Multiple Reactions Monitoring

NFDPM Nicotine-Free Dry Particulate Matter

PAH Polycyclic Aromatic Hydrocarbons

SIM Selective Ion Monitoring

TPM Total Particulate Matter

TTI Total Throughput Ion

\section{INTRODUCTION}

The carcinogenic properties of polycyclic aromatic hydrocarbons (PAHs) are well documented (1-7). Benzo $[a]$ pyrene $(\mathrm{B}[a] \mathrm{P})$ was first isolated from coal 'tar' in the 1930 s and its carcinogenicity demonstrated on the skin of mice (2). BLACKLOCK demonstrated its tumourigenic properties in the lungs of rats (3). It is one of the constituents of tobacco smoke identified and catalogued by WYNDER and HOFFMANN (4). It has been widely regarded as a standard marker of overall PAH exposure level in cigarette smoke (7). The testing of 44 so-called 'Hoffmann Analytes' is mandatory in Brazil and Canada and, since 2009, legislation passed in the United States, brought in new regulatory requirements for tobacco product brands marketed in the USA (8). The United States Food and Drug Administration (FDA) identified 93 harmful and potentially harmful constituents (HPHC) including 16 PAH compounds (Table 1). An abbreviated list containing $20 \mathrm{HPHC}$ compounds including $\mathrm{B}[a] \mathrm{P}$ was made compulsory for the industry in 2012 (9).

Table 1. PAH compounds defined by the FDA as harmful and potentially harmful constituents (HPHC)

\begin{tabular}{lc}
\hline Naphthalene * & \\
Benzo[c]phenanthrene & $\mathrm{B}[c] \mathrm{P}$ \\
Benz[a]anthracene & $\mathrm{B}[a] \mathrm{A}$ \\
Cyclopenta[c,d]pyrene & $\mathrm{C}[c d] \mathrm{P}$ \\
Chrysene & \\
5-Methylchrysene & $5-\mathrm{MC}$ \\
Benzo[b]fluoranthene & $\mathrm{B}[b] \mathrm{F}$ \\
Benzo[k]fluoranthene & $\mathrm{B}[k] \mathrm{F}$ \\
Benz[]aceanthrylene & $\mathrm{B}[] \mathrm{A}$ \\
Benzo[a]pyrene & $\mathrm{B}[a] \mathrm{P}$ \\
Indeno[1,2,3-cd] pyrene & $\mathrm{I}[c d] \mathrm{P}$ \\
Dibenz[a,h]anthracene & $\mathrm{dB}[a h] \mathrm{A}$ \\
Dibenzo[a,I]pyrene & $\mathrm{dB}[a] \mathrm{P}$ \\
Dibenzo[a,e]pyrene & $\mathrm{dB}[a e] \mathrm{P}$ \\
Dibenzo[a,j]pyrene & $\mathrm{dB}[a] \mathrm{P}$ \\
Dibenzo[a,h]pyrene & $\mathrm{dB}[a h] \mathrm{P}$ \\
\hline
\end{tabular}

* Strictly speaking naphthalene is a bicyclic aromatic hydrocarbon

PAHs consist of multiple aromatic rings formed through incomplete combustion of carbon fuel material such as tobacco (Figure 1). They are highly lipophilic and readily enter the biomass, being released back into the system by the process of lipolysis (10). They can be separated using high performance liquid chromatography (HPLC) and gas chromatography (GC), and analysed using fluorescence spectroscopy (HPLC-FLD) and mass spectrometry (LCMS, GC-MS). GC-MS analysis has been adopted into the ISO standardised method for $\mathrm{B}[a] \mathrm{P}$ in mainstream smoke [11]. Analysis of all of the remaining 15 PAHs on the FDA list provides certain challenges due to high matrix background in the smoke condensate extracts.

Advances in triple quadrupole mass spectrometry have enabled detection limits of $<1 \mathrm{ppb}$ in complex matrices to be realised (12). Removal of matrix interference across the triple-stage mass analyser and subsequent lowering of the baseline is the principle of the operation. Essentially it provides an added dimension of resolution compared to GCMS. Ions are resolved in the first quadrupole (Q1) by their 


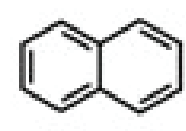

(a)

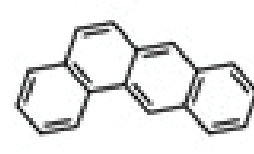

(b)

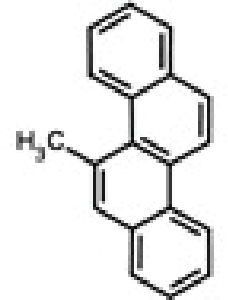

(c)

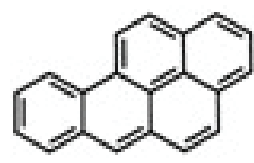

(d)

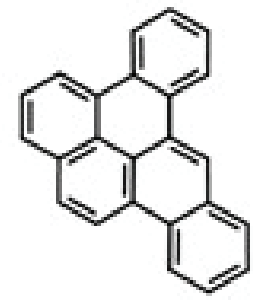

(e)

Figure 1. Examples of 2-, 4-, 5-, and 6-ring PAHs:

(a) Naphthalene; (b) Benz[a]anthracene; (c) 5-Methylchrysene; (d) Benzo[a]pyrene; (e) Dibenzo[a,e]pyrene. Figures obtained from Chemspider, free chemical database provided by the Royal Society of Chemistry

mass to charge $(\mathrm{m} / \mathrm{z})$ in the same way as single ion monitoring (SIM) would be used in a single-stage quadrople. A collision cell (Q2) is placed after Q1. This is actually a non-scanning hexapole held at total throughput ion (TTI). By application of a collision gas (nitrogen or argon) and a collision voltage $\left(\mathrm{C}_{\mathrm{v}}\right)$, further fragmentation of the ions occurs which are then resolved in the second quadrupole (Q3). This provides the system with its unique transition spectra known as multiple reaction monitoring (MRM). Data for $\mathrm{B}[a] \mathrm{P}$ yields in reference cigarettes are well established and have been generated from various inter-laboratory collaborations (13-16). Data has been gathered from laboratories using GC-MS and HPLC-FLD. The Cooperation Centre for Scientific Research Relative to Tobacco (CORESTA) recommended method for $\mathrm{B}[a] \mathrm{P}$ involves GC-MS (SIM) analysis (13). This is the standardised method ISO 22634 (11). Standardised smoking conditions are defined in ISO 3308 (17). Other smoking protocols such as the Health Canada Intense (HCI) (18) aim to more closely reflect potential maximum levels. A collaborative study conducted by CORESTA, in 2012, involving 16 laboratories, reported mean yield, repeatability (r) and reproducibility $(\mathrm{R})$ data from 10 cigarette brands including two University of Kentucky reference cigarettes, K3R4F and K1R5F, and the CORESTA monitor CM6 under ISO and $\mathrm{HCI}$ protocols. $\mathrm{B}[a] \mathrm{P}$ levels generally correlate well with 'tar' levels or more specifically the nicotine-free dry particulate matter (NFDPM): K3R4F (NFDPM $8 \mathrm{mg} / \mathrm{cig}$; ISO mean $6.66 \mathrm{ng} / \mathrm{cig}, \mathrm{R}=2.00$; HCI mean $15.51 \mathrm{ng} / \mathrm{cig}$, $\mathrm{R}=4.93$ ), K1R5F (NFDPM $2 \mathrm{mg} / \mathrm{cig}$; ISO mean 1.64 $\mathrm{ng} / \mathrm{cig}, \mathrm{R}=0.80$; HCI mean $7.13 \mathrm{ng} / \mathrm{cig}, \mathrm{R}=2.28$ ), and CM6 (NFPDM $15 \mathrm{mg} / \mathrm{cig}$; ISO mean $15.48 \mathrm{ng} / \mathrm{cig}$, $\mathrm{R}=5.19$; HCI mean $27.86 \mathrm{ng} / \mathrm{cig}, \mathrm{R}=8.45$ ) (13).

Various studies have been conducted to assess PAH yields in cigarettes (19-23). Yield data from reference cigarettes is limited, however, studies of the K1R4F (NFDPM 8 $\mathrm{mg} / \mathrm{cig}$ ) have been reported for some PAHs on the FDA list (20-22). RODGMAN and GREEN reported ISO values for naphthalene (342 ng/cig), benz $[a]$ anthracene $(\mathrm{B}[a] \mathrm{A})$ (12.4 ng/cig), benzo[b]fluoranthene (B[b]F) (5.5 ng/cig), benzo $[k]$ fluoranthene $(\mathrm{B}[k] \mathrm{F}(1.3 \mathrm{ng} / \mathrm{cig}), \mathrm{B}[a] \mathrm{P}(5.7 \mathrm{ng}$ $/ \mathrm{cig})$, chrysene (13.6 ng/cig), dibenz $[a, h]$ anthracene $(\mathrm{dB}[a h] \mathrm{A})(0.4 \mathrm{ng} / \mathrm{cig})$, indeno[1,2,3-cd]pyrene (I[cd]P) (3.5 ng/cig), and naphthalene (342 ng/cig) (22). ROEMER et al. reported PAH ISO values for the K2R4F which super- seded the K1R4F (23). The same group also reported ISO and $\mathrm{HCI}$ values for the next iteration K3R4F: B[a]A (ISO $11.8 \mathrm{ng} / \mathrm{cig}, \mathrm{HCI} 29.8 \mathrm{ng} / \mathrm{cig}$ ), B[b]F (ISO $5.09 \mathrm{ng} / \mathrm{cig}$; HCI $13.2 \mathrm{ng} / \mathrm{cig}$ ), B[k]F (ISO $2.02 \mathrm{ng} / \mathrm{cig}$; HCI 5.38 ng/cig), B[a]P (ISO 6.73 ng/cig; HCI 16.2 ng/cig)), I[cd]P (ISO $2.87 \mathrm{ng} / \mathrm{cig}$; HCI $7.37 \mathrm{ng} / \mathrm{cig}$ ), and dibenzo$[a, e]$ pyrene $\mathrm{dB}[a e] \mathrm{P}$ (ISO $0.173 \mathrm{ng} / \mathrm{cig} ; \mathrm{HCI} 0.858 \mathrm{ng} / \mathrm{cig}$ ). Other PAHs, $\mathrm{dB}[a h] \mathrm{A}$, dibenzo $[a, h]$ pyrene $(\mathrm{dB}[a h] \mathrm{P})$, dibenzo $[a, i]$ pyrene $(\mathrm{dB}[a i] \mathrm{P})$, dibenzo $[a, l]$ pyrene $(\mathrm{dB}[a l] \mathrm{P}$ and 5-methylchrysene (5-MC), were reported below LOQ under both regimes.

Validated data for the determination of 16 PAH compounds using an adapted version of ISO 22634, under ISO and HCI smoking regimes are presented in this manuscript.

\section{EXPERIMENTAL}

\section{Materials and equipment}

The Kentucky reference cigarettes were supplied by the Kentucky Tobacco Research and Development Center (Lexington, KY, USA). CORESTA monitor cigarettes were supplied by Cerulean (Milton Keynes, UK). Branded cigarettes were purchased in the United States. The cigarettes were smoked on a 20-port rotary smoking machine (RM20/CS or RM20D, Borgwaldt, Hamburg, Germany) compliant with ISO 3308 (17). Linear smoking was performed using a Cerulean SM450. Materials used for smoking and extraction are outlined in ISO 22634 (11). Cambridge filter $(\mathrm{CF})$ glass fibre pads were manufactured by Whatman (Maidstone, UK) and supplied by Cerulean. Solid-phase extraction (SPE) $\mathrm{CH}(\mathrm{EC})$ cartridges (1 g, $10 \mathrm{~mL}$ ) were supplied by Biotage (Cardiff, UK). TurboVap was supplied by Biotage. Analyte stock standards were supplied by Accustandard (New Haven, CT, USA) and Toronto Research Chemicals (Toronto, Canada). Deuterated PAH analogues used as internal standards were supplied by Cambridge Isotope Laboratories (Andover, MA, USA). The analysis was performed using GC-MS/MS (7890GC-7000MS/MS, Agilent, Santa Clara, CA, USA). Components were separated using a J\&W PAH SELECT $(30 \mathrm{~m} \times 0.25 \mathrm{~mm}, 0.15 \mathrm{~mm})$ column (Agilent). Peak integration and processing was performed using Mass Hunter software (Agilent). Gases used were helium and nitrogen (>99.999\%). 


\section{Sample preparation}

All cigarettes were conditioned in accordance with ISO 3402 (24). NFDPM values were determined using a linear smoking machine in accordance with ISO 4387 (25). Smoking was carried out in accordance with ISO 3308 (17) and HCI (18) protocols. Smoking parameters are outlined in Table 2. For HCI smoking all filter ventilation holes were blocked. Smoking for PAHs was performed using a rotary smoking machine. The smoke condensate from 20 cigarettes (ISO) and 10 cigarettes (HCI) was trapped onto a $92 \mathrm{~mm} \mathrm{CF}$ pad. TPM values were obtained for all of the samples in accordance with ISO 4387 (25). The extraction and clean-up procedure is outlined in ISO 22634 (11). The CF pad was spiked with internal standard solution then extracted into $50 \mathrm{~mL}$ methanol, shaken to disintegration and filtered through a Buchner funnel. The filtrate was diluted with water to approximately $60 \%$ then the clean-up was performed using $\mathrm{CH}(\mathrm{EC})$ cartridge. PAHs were eluted with $15 \mathrm{~mL}$ cyclohexane prior to concentration to $1 \mathrm{~mL}$ using a TurboVap.

Table 2. ISO and $\mathrm{HCl}$ smoking regimes

\begin{tabular}{l|c|c|c|c}
\hline Smoking regime & $\begin{array}{c}\text { Puff volume } \\
(\mathrm{mL})\end{array}$ & $\begin{array}{c}\text { Puff } \\
\text { frequency } \\
(\mathrm{s})\end{array}$ & $\begin{array}{c}\text { Puff } \\
\text { duration } \\
(\mathrm{s})\end{array}$ & $\begin{array}{c}\text { Ventilation } \\
\text { blocking } \\
(\%)\end{array}$ \\
\hline ISO 3308:2009 & 35 & 60 & 2 & 0 \\
HCl T-115 & 55 & 30 & 2 & 100 \\
\hline
\end{tabular}

\section{$G C-M S / M S$}

The inlet was held at $300{ }^{\circ} \mathrm{C}(1 \mathrm{~mL}$; splitless $1 \mathrm{~min})$. The carrier gas was helium $(1.2 \mathrm{~mL} / \mathrm{min})$. Oven start temperature was $60{ }^{\circ} \mathrm{C}(1 \mathrm{~min})$ then ramped at $25{ }^{\circ} \mathrm{C} / \mathrm{min}$ to $150{ }^{\circ} \mathrm{C}(0.5 \mathrm{~min})$ then $3{ }^{\circ} \mathrm{C} / \mathrm{min}$ to $325^{\circ} \mathrm{C}(12 \mathrm{~min})$. Transfer line was held at $310^{\circ} \mathrm{C}$. The ion source was held at $300{ }^{\circ} \mathrm{C}(\mathrm{EI} ; 70 \mathrm{eV})$. Helium quench gas and nitrogen were supplied to the collision cell $(2.3$ and $1.5 \mathrm{~mL} / \mathrm{min}$, respectively).

Table 3. Analytes and deuterated internal standards

\begin{tabular}{ll}
\hline Analyte & Internal standard \\
\hline Naphthalene & Naphthalene D8 \\
Benzo[c]phenanthrene & Benz[a]anthracene D12 \\
Benz[a]anthracene & Benz[a]anthracene D12 \\
Cyclopenta[c,d]pyrene & Benz[a]anthracene D12 \\
Chrysene & Chrysene D12 \\
5-Methylchrysene & 5-Methylchrysene D3 \\
Benzo[b]fluoranthene & Benzo[b]fluoranthene D12 \\
Benzo[k]fluoranthene & Benzo[k]fluoranthene D12 \\
Benz[j]aceanthrylene & B[a]P D12 \\
B[a]P & B[a]P D12 \\
Indeno[1,2,3-cd]pyrene & Indeno[1,2,3-cd]pyrene D12 \\
Dibenzo[a, $h]$ anthracene & Dibenzo[a,h]anthracene D14 \\
Dibenzo[a,Ijpyrene & Dibenzo[a,i]pyrene D14 \\
Dibenzo[a,e]pyrene & Dibenzo[a,i]pyrene D14 \\
Dibenzo[a,i]pyrene & Dibenzo[a,i]pyrene D14 \\
Dibenzo[a, $h]$ pyrene & Dibenzo[a,i]pyrene D14 \\
\hline
\end{tabular}

\section{Calibration and internal standards}

Standards were prepared in hexane of $16 \mathrm{PAH}$ analytes in a concentration range of 2 to $200 \mathrm{ng} / \mathrm{mL}$ (except $\mathrm{B}[a] \mathrm{A}$, chrysene 4 to $400 \mathrm{ng} / \mathrm{mL}$ and naphthalene 200 to $5000 \mathrm{ng} / \mathrm{mL}$ ). Deuterated analogues of 10 components were added as internal standards (ISTDs) and spiked onto the Cambridge filter pads prior to addition of extraction solvent. Six compounds were quantified using surrogate internal standards (Table 3).

\section{Limit of detection/Limit of quantification}

Ten analyses of the lowest calibration standard were ran on 10 separate sequence runs. Calculated values within $\pm 15 \%$ of the nominal value were obtained and the LOD was defined as $3 \times$ standard deviation (SD) and the LOQ defined as $10 \times \mathrm{SD}$. The units were converted into nanograms per cigarette (ng/cig).

\section{K3R $4 F$ analysis}

PAHs were determined for the K3R4F under ISO and HCI smoking regimes. Analyses were performed in triplicate and 10 determinations made for each regime on separate days. The overall mean and standard error were calculated from the individual mean value from each determination. The intraday precision was calculated from the individual SD value from each determination.

The relative recoveries were determined by pad spiking K3R4F extracts: calibration level 2 (CL2) 5:10:500 ng/mL; CL3 10:20:1000 ng/mL; and CL4 20:40:2000 ng/mL, prior to addition of extraction solvent. A pad spike at each level and an unspiked monitor were run in triplicate.

\section{Branded and other reference cigarettes}

Five branded cigarettes and two other reference cigarettes (CM7 and K1R5F) were analysed under ISO smoking conditions. All branded cigarettes were ventilated. Brands A to $\mathrm{C}$ were standard circumference, Brands D and $\mathrm{E}$ were Slim type cigarettes. One analysis was performed in triplicate. A K3R4F determination was also run as a control.

\section{RESULTS AND DISCUSSION}

\section{K3R $4 F$ yield data}

The PAH yields along with the standard errors are shown in Table 4. There were 15 quantifiable compounds. Only $\mathrm{dB}[a l] \mathrm{P}$ was determined to be below LOD. $\mathrm{B}[a] \mathrm{P}$ levels were consistent with published data and our own data using the GC-MS method. Naphthalene was by far the most abundant (ISO mean $365 \mathrm{ng} / \mathrm{cig}$ and HCI mean $1595 \mathrm{ng} / \mathrm{cig}$ ) but also quite variable under ISO conditions (CV 20.5\%). The remaining 14 PAHs were present between 0.16 and $13.95 \mathrm{ng} / \mathrm{cig}$ (ISO). The most variable data, $\mathrm{dB}[a i] \mathrm{P}$ and $\mathrm{dB}[a h] \mathrm{P}$ (CV 24.3-24.8\% ISO), were also detected at the lowest levels (0.16-0.17 ng/cig ISO). This was close to the LOQs for these compounds. Generally mean yields were more variable under ISO conditions. 
Table 4. $\mathrm{PAH}$ mean yields in the $\mathrm{K} 3 \mathrm{R} 4 \mathrm{~F}$ under $\mathrm{ISO}$ and $\mathrm{HCl}$ regimes

\begin{tabular}{|c|c|c|c|c|}
\hline \multirow{2}{*}{$\mathrm{PAH}$ ISO and $\mathrm{HCl}$ mean yields } & \multicolumn{2}{|c|}{ K3R4F ISO (TPM 10.0 mg/cig; n = 30) } & \multicolumn{2}{|c|}{ K3R4F HCl (TPM 40.4 mg/cig; $\mathrm{n}=30$ ) } \\
\hline & $\mathrm{ng} / \mathrm{cig}$ & SE & $\mathrm{ng} / \mathrm{cig}$ & SE \\
\hline Naphthalene & 365.20 & 74.40 & 1594.80 & 153.00 \\
\hline Benzo[c]phenanthrene & 1.19 & 0.16 & 3.05 & 0.20 \\
\hline Benz[a]anthracene & 10.90 & 1.13 & 28.17 & 1.70 \\
\hline Cyclopenta[c,d]pyrene & 6.75 & 0.59 & 17.69 & 1.21 \\
\hline Chrysene & 13.95 & 1.67 & 32.39 & 3.76 \\
\hline 5-Methylchrysene & 1.09 & 0.21 & 2.73 & 0.55 \\
\hline Benzo[b]fluoranthene & 4.65 & 0.60 & 12.81 & 0.98 \\
\hline Benzo $[k]$ fluoranthene & 2.03 & 0.29 & 5.05 & 0.37 \\
\hline Benz[]]aceanthrylene & 1.48 & 0.27 & 3.69 & 0.69 \\
\hline $\mathrm{B}[\mathrm{a}] \mathrm{P}$ & 6.07 & 0.79 & 15.64 & 1.29 \\
\hline Indeno[1,2,3-cd]pyrene & 2.72 & 0.37 & 6.81 & 0.58 \\
\hline Dibenzo[a, $h]$ anthracene & 0.66 & 0.10 & 1.73 & 0.15 \\
\hline Dibenzo[a,/]pyrene & $<$ LOD & $N / A$ & $<$ LOD & $\mathrm{N} / \mathrm{A}$ \\
\hline Dibenzo[a,e]pyrene & 0.24 & 0.03 & 0.62 & 0.12 \\
\hline Dibenzo[a,i]pyrene & 0.17 & 0.04 & 0.39 & 0.10 \\
\hline Dibenzo[a, $h]$ pyrene & 0.16 & 0.04 & 0.33 & 0.07 \\
\hline
\end{tabular}

This may reflect variability of the TPM (CV 7.0\% ISO, $3.4 \% \mathrm{HCI}$ ). Different rotary smoking machines were used and although strict tolerance limits on the TPM were employed it was observed that small differences in TPM greatly affected overall PAH yields. Yields under HCI conditions were generally 2 to 3 times higher compared with ISO. The higher yields, hence more signal, may explain the greater precision observed. No significant difference was observed in the overall precision between PAHs with deuterated analogue ISTDs and those with surrogate ISTDs. The intraday precision was also highest for the lowest yielding PAHs (Table 5).

\section{Chromatography and mass spectral analysis}

Positive identification was based on a retention time (RT) match $( \pm 1 \mathrm{~s})$ of the peak apex of the sample against the peak apex of a calibration check standard. PAHs were resolved by multiple reaction monitoring (MRM) or tandem selected ion monitoring (t-SIM) (Table 6). The dwell and $\mathrm{C}_{\mathrm{v}}$ were optimised using product ion scan. Peaks are shown to be clearly resolved from the matrix (Figure 2). Background noise and matrix interference were found to be minimal compared with GC-MS. The SELECT PAH column is a moderately polar phase type, therefore, separation was by volatility and polarity. Structural isomers were clearly separated.

\section{Limit of detection/quantification}

Repeat analyses of the lowest calibration standard were used to calculate LOD/LOQ (Table 7). It is an empirical measurement based on a procedure outlined in the Health Canada official method for the determination of $\mathrm{B}[a] \mathrm{P}$ in mainstream cigarette smoke (26). The selectivity of the method and detection of certain PAHs at very low levels do suggest that these threshold levels are achievable despite the matrix present.
Table 5. Intraday precision derived from the average SD from the K3R4F data, expressed as a percentage (CV.r (\%)), under ISO and $\mathrm{HCl}$ regimes

\begin{tabular}{lcc}
\hline Analyte & CV.r (\%) ISO & CV.r (\%) $\mathrm{HCl}$ \\
\hline Naphthalene & 6.3 & 5.1 \\
Benzo[c]phenanthrene & 4.6 & 4.3 \\
Benz[a]anthracene & 3.9 & 3.1 \\
Cyclopenta[c, d]pyrene & 3.9 & 4.1 \\
Chrysene & 4.3 & 3.1 \\
5-Methylchrysene & 5.1 & 5.9 \\
Benzo[b]fluoranthene & 2.8 & 3.2 \\
Benzo[k]fluoranthene & 4.7 & 3.9 \\
Benz[]aceanthrylene & 8.2 & 5.6 \\
B[a]P & 3.2 & 3.2 \\
Indeno[1,2,3-cd]pyrene & 3.1 & 3.3 \\
Dibenzo[a,h]anthracene & 4.3 & 5.0 \\
Dibenzo[a,I]pyrene & $\mathrm{N} / \mathrm{A}$ & $\mathrm{N} / \mathrm{A}$ \\
Dibenzo[a,e]pyrene & 12.3 & 8.6 \\
Dibenzo[a,]pyrene & 19.1 & 11.9 \\
Dibenzo[a,h]pyrene & 19.4 & 14.8 \\
\hline
\end{tabular}

\section{Branded cigarettes and other monitor data}

A comparison of PAH yields between 5 branded cigarettes and 3 reference cigarettes is shown in Table 8 . In all products only $\mathrm{dB}[a l] \mathrm{P}$ was determined to be below LOD. The CM7 was the only non-ventilated filter product with the highest TPM $(15.3 \mathrm{mg} / \mathrm{cig})$ and produced the highest PAH yields. The K1R5F produced the lowest with 2 components determined $<$ LOQ. Sample A contained the highest PAH yields of the branded products. Sample B was the highest yielding TPM (14.6 mg/cig) product and contained the second highest PAH yields. However, 'tar' yields obtained from linear smoking under ISO 4387 (25) found NFDPM in Samples A and B to be closer than the TPM data from rotary smoking (Table 9). 
Table 6. Transition ions $(\mathrm{m} / \mathrm{z})$ and analyser settings

\begin{tabular}{|c|c|c|c|c|}
\hline Analyte & MRM quantifier (qualifier) & Collision energy $(\mathrm{V})$ & Dwell (ms) & $\mathrm{RT}$ (min) \\
\hline Naphthalene D8 & $136.1 \rightarrow 108.1$ & 25 & 10 & 5.14 \\
\hline Naphthalene & $128.1 \rightarrow 102.1(128.1 \rightarrow 78.0)$ & $20(25)$ & $15(15)$ & 5.16 \\
\hline Benzo[c]phenanthrene & $228.0 \rightarrow 226.1$ & 40 & 115 & 17.57 \\
\hline Benz[a]anthracene D12 & $240.0 \rightarrow 236.1$ & 40 & 36 & 18.57 \\
\hline Benz[a]anthracene & $228.0 \rightarrow 228.1$ & 20 & 100 & 18.72 \\
\hline Cyclopenta[c, $d]$ pyrene & $225.9 \rightarrow 224.1$ & 40 & 100 & 19.07 \\
\hline Chrysene D12 & $240.0 \rightarrow 236.1$ & 40 & 36 & 19.00 \\
\hline Chrysene & $228.0 \rightarrow 228.1$ & 20 & 100 & 19.18 \\
\hline 5-Methylchrysene D3 & $245.0 \rightarrow 244.1$ & 20 & 25 & 21.70 \\
\hline 5-Methylchrysene & $242.0 \rightarrow 241.1(242.0 \rightarrow 226.1)$ & $20(35)$ & $67(67)$ & 21.78 \\
\hline Benzo[b]fluoranthene D12 & $264.0 \rightarrow 264.2$ & 20 & 20 & 25.50 \\
\hline Benzo[b]fluoranthene & $252.0 \rightarrow 252.1(252.0 \rightarrow 250.1)$ & $20(35)$ & $100(100)$ & 25.69 \\
\hline Benzo[k]fluoranthene D12 & $264.0 \rightarrow 264.2$ & 20 & 20 & 25.59 \\
\hline Benzo[k]fluoranthene & $252.0 \rightarrow 252.1(252.0 \rightarrow 250.1)$ & $20(35)$ & $100(100)$ & 25.84 \\
\hline Benz[]]aceanthrylene & $252.0 \rightarrow 252.1(252.0 \rightarrow 250.1)$ & $20(45)$ & $110(110$ & 26.70 \\
\hline $\mathrm{B}[\mathrm{a}] \mathrm{P} \mathrm{D} 12$ & $264.2 \rightarrow 260.2$ & 45 & 30 & 28.11 \\
\hline $\mathrm{B}[\mathrm{a}] \mathrm{P}$ & $252.0 \rightarrow 252.1(252.0 \rightarrow 250.1)$ & $20(45)$ & $110(110)$ & 28.29 \\
\hline Indeno[1,2,3-cd]pyrene D12 & $288.0 \rightarrow 288.2$ & 30 & 30 & 34.85 \\
\hline Indeno[1,2,3-cd]pyrene & $276.0 \rightarrow 276.1$ & 30 & 80 & 35.03 \\
\hline Dibenzo[a,h]anthracene D14 & $292.0 \rightarrow 288.3$ & 40 & 30 & 34.86 \\
\hline Dibenzo[a,h]anthracene & $278.0 \rightarrow 278.1$ & 30 & 125 & 35.07 \\
\hline Dibenzo[a,i]pyrene D14 & $316.0 \rightarrow 316.2$ & 20 & 50 & 46.82 \\
\hline Dibenzo[a,/]pyrene & $302.0 \rightarrow 302.1(302.0 \rightarrow 300.1)$ & $20(40)$ & $160(100)$ & 43.30 \\
\hline Dibenzo[a,e]pyrene & $302.0 \rightarrow 302.1(302.0 \rightarrow 300.1)$ & $20(40)$ & $160(100)$ & 45.71 \\
\hline Dibenzo[a,i]pyrene & $302.0 \rightarrow 302.1(302.0 \rightarrow 300.1)$ & $20(40)$ & $160(100)$ & 47.15 \\
\hline Dibenzo[a, $h]$ pyrene & $302.0 \rightarrow 302.1(302.0 \rightarrow 300.1)$ & $20(40)$ & $160(100)$ & 47.92 \\
\hline
\end{tabular}

Table 7. Limits of detection/quantification (LOD/LOQ)

\begin{tabular}{|c|c|c|c|c|}
\hline Analyte & $\begin{array}{l}\text { ISO LOD } \\
\text { (ng/cig) }\end{array}$ & $\begin{array}{c}\text { ISO LOQ } \\
\text { (ng/cig) }\end{array}$ & $\begin{array}{c}\mathrm{HCI} L O D \\
\text { (ng/cig) }\end{array}$ & $\begin{array}{c}\text { HCO LOQ } \\
\text { (ng/cig) }\end{array}$ \\
\hline Naphthalene & 2.89 & 9.62 & 5.77 & 19.24 \\
\hline Benzo[c]phenanthrene & 0.02 & 0.08 & 0.05 & 0.15 \\
\hline Benz[a]anthracene & 0.06 & 0.20 & 0.12 & 0.39 \\
\hline Cyclopenta $[c, d]$ pyrene & 0.03 & 0.09 & 0.05 & 0.17 \\
\hline Chrysene & 0.04 & 0.12 & 0.07 & 0.25 \\
\hline 5-Methylchrysene & 0.02 & 0.05 & 0.03 & 0.11 \\
\hline Benzo[b]fluoranthene & 0.02 & 0.08 & 0.05 & 0.15 \\
\hline Benzo[ $k]$ fluoranthene & 0.02 & 0.06 & 0.04 & 0.13 \\
\hline Benz[]]aceanthrylene & 0.05 & 0.16 & 0.10 & 0.33 \\
\hline $\mathrm{B}[\mathrm{a}] \mathrm{P}$ & 0.01 & 0.04 & 0.02 & 0.08 \\
\hline Indeno[1,2,3-cd] pyrene & 0.02 & 0.08 & 0.05 & 0.17 \\
\hline Dibenz $[a, h]$ anthracene & 0.02 & 0.08 & 0.05 & 0.16 \\
\hline Dibenzo[a,/]pyrene & 0.04 & 0.13 & 0.08 & 0.25 \\
\hline Dibenzo[a,e]pyrene & 0.03 & 0.10 & 0.06 & 0.20 \\
\hline Dibenzo[a,i]pyrene & 0.02 & 0.07 & 0.04 & 0.14 \\
\hline Dibenzo[a,h]pyrene & 0.03 & 0.11 & 0.07 & 0.23 \\
\hline
\end{tabular}


(a)

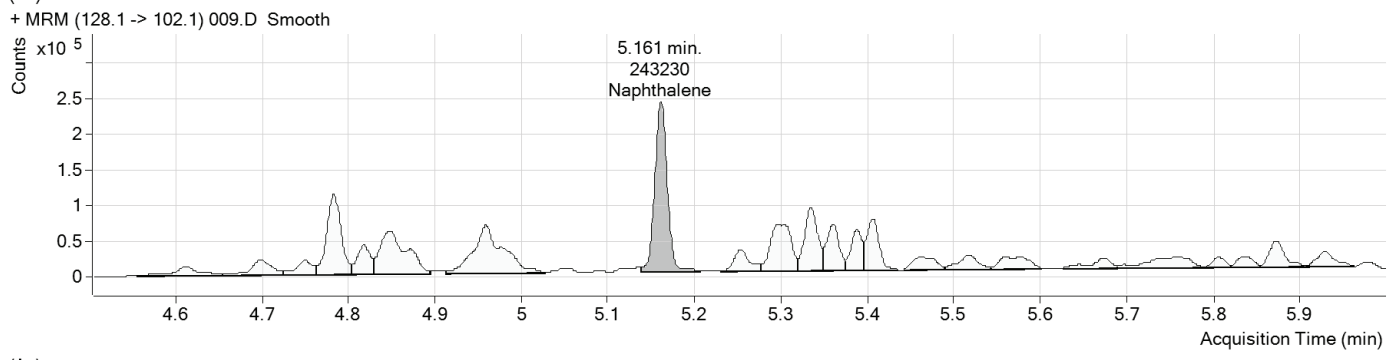

(b)

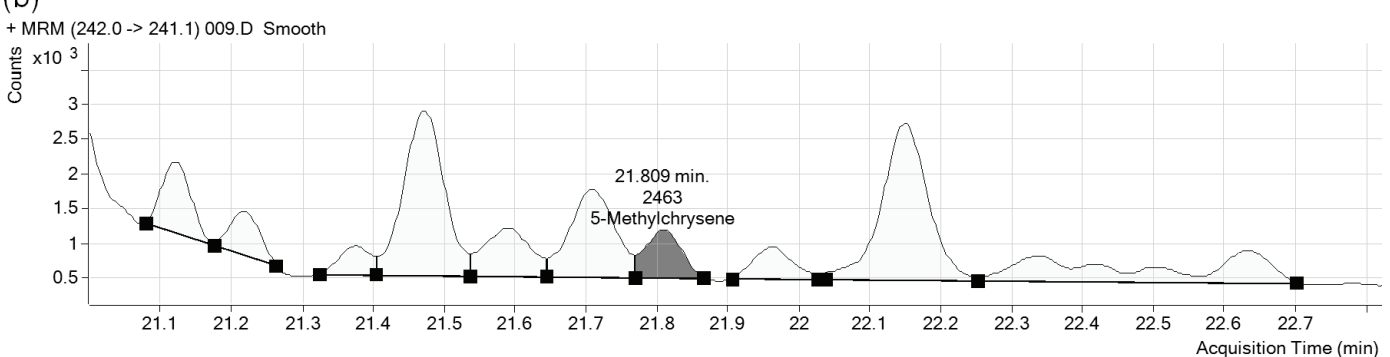

(c)

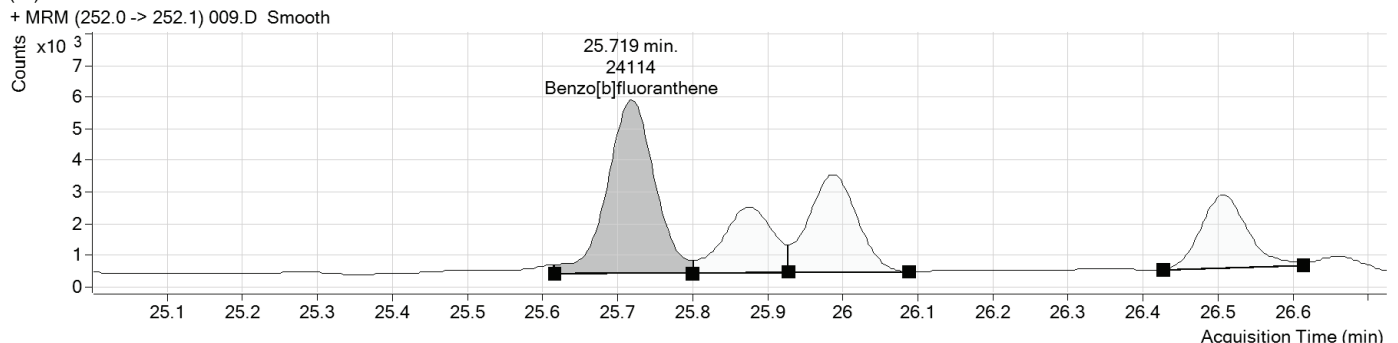

(d)

+ MRM $(252.0->$ 252.1) 009.D Smooth

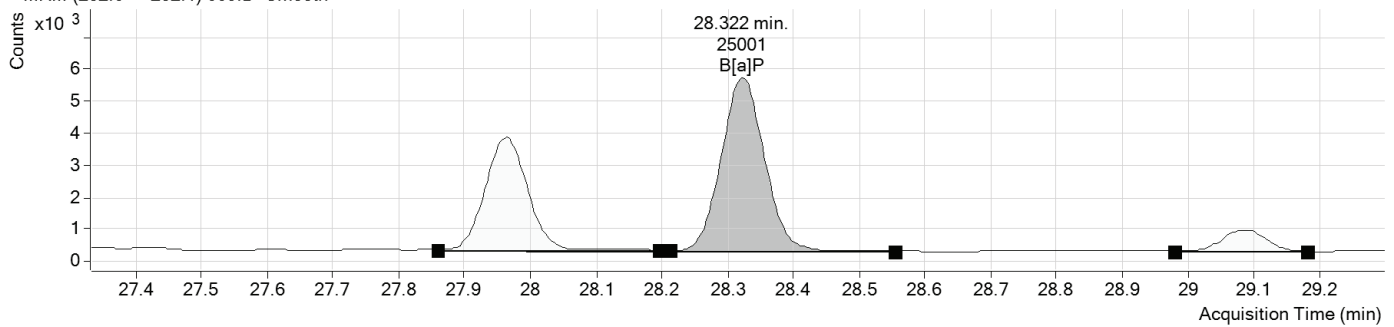

(e)

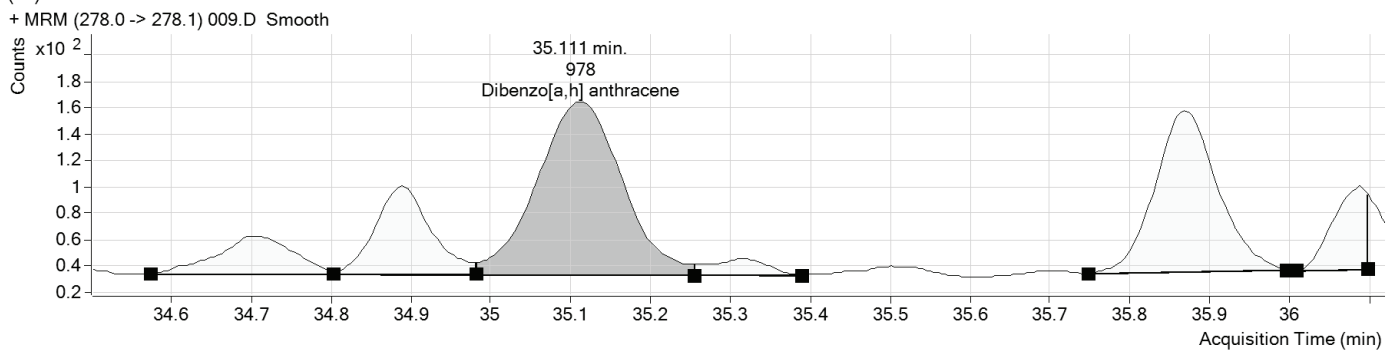

(f)

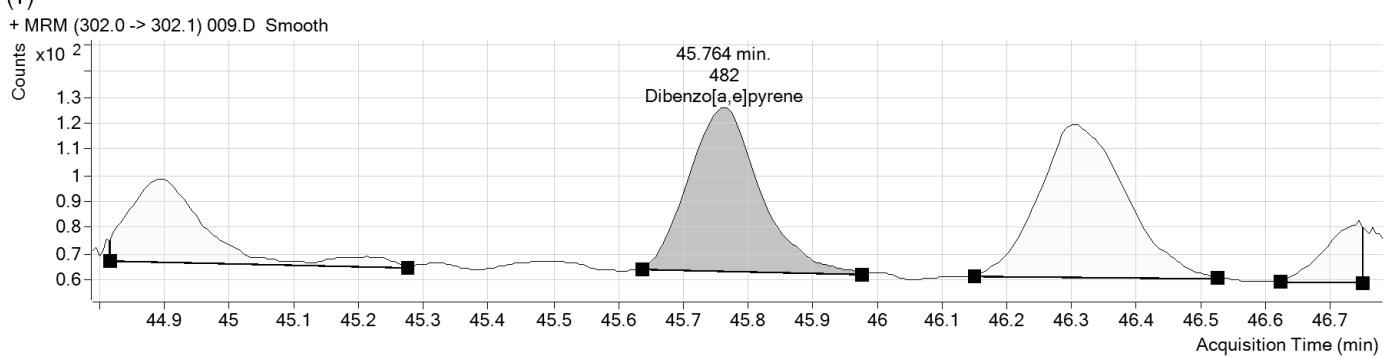

Figure 2. Selected chromatograms from K3R4F extracts:

(a) Naphthalene; (b) 5-MC; (c) B[b]F; (d) B[a]P; (e) dB[ah]A; (f) dB[ae]P 
Table 8. Comparison of PAH yields of branded and reference cigarettes

\begin{tabular}{l|c|c|c|c|c|c|c|c}
\hline Sample & K3R4F & K1R5F & CM7 & Sample A & Sample B & Sample C & $\begin{array}{c}\text { Sample } \\
\text { D slim }\end{array}$ & $\begin{array}{c}\text { Sample } \\
\text { E slim }\end{array}$ \\
\hline TPM (mg/cig; $n=3)$ & 9.8 & 2.3 & 15.3 & 11.9 & 14.6 & 10.0 & 9.7 & 6.8 \\
\hline PAH ISO mean yields & $\mathrm{ng} / \mathrm{cig}$ & $\mathrm{ng} / \mathrm{cig}$ & $\mathrm{ng} / \mathrm{cig}$ & $\mathrm{ng} / \mathrm{cig}$ & $\mathrm{ng} / \mathrm{cig}$ & $\mathrm{ng} / \mathrm{cig}$ & $\mathrm{ng} / \mathrm{cig}$ & $\mathrm{ng} / \mathrm{cig}$ \\
\hline Naphthalene & 461.1 & 192.3 & 1542.7 & 606.0 & 508.5 & 578.9 & 554.0 & 415.4 \\
Benzo[c]phenanthrene & 1.28 & 0.44 & 3.26 & 2.29 & 1.85 & 1.33 & 0.99 & 0.78 \\
Benz[a]anthracene & 11.48 & 3.05 & 24.71 & 17.48 & 14.78 & 11.30 & 7.66 & 5.84 \\
Cyclopenta[c,d]pyrene & 7.38 & 2.37 & 21.28 & 13.53 & 10.77 & 7.77 & 5.21 & 3.74 \\
Chrysene & 16.42 & 4.75 & 41.06 & 24.07 & 20.34 & 16.03 & 10.76 & 8.98 \\
5-Methylchrysene & 1.24 & 0.31 & 2.20 & 1.60 & 1.55 & 1.15 & 0.81 & 0.62 \\
Benzo[b]fluoranthene & 5.37 & 1.99 & 16.72 & 8.81 & 7.46 & 5.55 & 3.71 & 2.75 \\
Benzo[k]fluoranthene & 2.26 & 0.77 & 8.06 & 4.24 & 3.38 & 2.29 & 1.50 & 1.15 \\
Benz[]aceanthrylene & 1.50 & 0.65 & 4.53 & 2.14 & 2.15 & 1.60 & 1.19 & 0.89 \\
B[a]P & 6.88 & 2.00 & 18.39 & 10.81 & 9.11 & 6.69 & 4.38 & 3.37 \\
Indeno[1,2,3-cd] pyrene & 3.01 & 0.93 & 8.45 & 4.75 & 4.12 & 2.99 & 1.98 & 1.52 \\
Dibenz[a, $h$ ]anthracene & 0.72 & 0.23 & 1.78 & 0.99 & 0.94 & 0.70 & 0.48 & 0.35 \\
Dibenzo[a,I]pyrene & $<\mathrm{LOD}$ & $<$ LOD & $<\mathrm{LOD}$ & $<$ LOD & $<$ LOD & $<$ LOD & $<$ LOD & $<$ LOD \\
Dibenzo[a,e]pyrene & 0.30 & 0.10 & 0.67 & 0.39 & 0.36 & 0.24 & 0.18 & 0.13 \\
Dibenzo[a,]pyrene & 0.18 & $<0.07$ & 0.36 & 0.22 & 0.20 & 0.12 & 0.08 & 0.07 \\
Dibenzo[a,h]pyrene & 0.19 & $<0.11$ & 0.29 & 0.21 & 0.20 & 0.13 & $<0.11$ & $<0.11$ \\
\hline
\end{tabular}

Table 9. Comparison of 'tar' yields from rotary and linear machine smoking

\begin{tabular}{l|c|c|c}
\hline \multirow{2}{*}{ Product } & Rotary ISO 4387 & \multicolumn{2}{|c}{ Linear ISO 4387 } \\
\cline { 2 - 4 } & TPM (mg/cig) & TPM (mg/cig) & $\begin{array}{r}\text { NFDPM } \\
\text { (mg/cig) }\end{array}$ \\
\hline K3R4F & 9.8 & 9.8 & 8.5 \\
K1R5F & 2.3 & 2.2 & 1.9 \\
CM7 & 15.3 & 16.5 & 13.7 \\
Sample A & 11.9 & 11.9 & 9.8 \\
Sample B & 14.6 & 13.4 & 11.1 \\
Sample C & 10.0 & 10.6 & 8.9 \\
Sample D & 9.7 & 9.8 & 8.6 \\
Sample E & 6.8 & 7.5 & 6.5 \\
\hline
\end{tabular}

Slim type samples $\mathrm{D}$ and $\mathrm{E}$ produced the lowest $\mathrm{PAH}$ yields; $\mathrm{dB}[a h] \mathrm{P}$ was $<$ LOQ in these products. 'Tar' level was shown to be the main driver of PAH yields but type of ventilation, tobacco blend and circumference must also be factors to consider. American type blends have been found to yield less $\mathrm{B}[a] \mathrm{P}$ per unit of 'tar' than Virginia blends (27). Yields of $\mathrm{B}[a] \mathrm{P}$ proportional to the other PAHs was widely consistent across all of the products. The exception was naphthalene which may reflect the variance found in the K3R4F validation data.

\section{Recoveries}

The relative recoveries were calculated from the percentage ratio of the actual versus theoretical mean from 3 spiked and 3 unspiked K3R4F replicates at 3 CLs (Table 10). Recoveries were acceptable in all cases and ranged from $83.4 \%$ to $124.2 \%$. All the recoveries except three were within $15 \%$ of the nominal values. Greater accuracy was observed using analogue ISTDS $(86.7 \%$ to $107.7 \%)$ compared with surrogates ISTDs (83.4 \% to $124.2 \%)$. Pads spiked at CL2 were equivalent to addition of
Table 10. Relative recoveries obtained at 3 calibration levels

\begin{tabular}{lrr|r}
\hline & CL2 & \multicolumn{1}{c}{ CL3 } & \multicolumn{1}{c}{ CL4 } \\
\hline Naphthalene & $105.5 \%$ & $105.4 \%$ & $107.7 \%$ \\
Benzo[c]phenanthrene & $90.7 \%$ & $80.8 \%$ & $85.2 \%$ \\
Benz[a]anthracene & $98.4 \%$ & $92.8 \%$ & $91.5 \%$ \\
Cyclopenta[c, $d$ ]pyrene & $112.2 \%$ & $111.0 \%$ & $124.2 \%$ \\
Chrysene & $103.2 \%$ & $102.2 \%$ & $101.7 \%$ \\
5-Methylchrysene & $98.6 \%$ & $93.7 \%$ & $86.7 \%$ \\
Benzo[b]fluoranthene & $103.6 \%$ & $98.4 \%$ & $95.2 \%$ \\
Benzo[k]fluoranthene & $98.3 \%$ & $104.7 \%$ & $102.9 \%$ \\
B[a]P & $101.0 \%$ & $99.8 \%$ & $97.0 \%$ \\
Indeno[1,2,3-cd] pyrene & $98.1 \%$ & $90.4 \%$ & $96.3 \%$ \\
Dibenz[a,h]anthracene & $101.9 \%$ & $97.5 \%$ & $96.0 \%$ \\
Dibenzo[a,, pyrene & $93.0 \%$ & $111.9 \%$ & $99.6 \%$ \\
Dibenzo[a,e]pyrene & $84.5 \%$ & $112.7 \%$ & $83.4 \%$ \\
Dibenzo[a,I]pyrene & $91.8 \%$ & $94.8 \%$ & $88.0 \%$ \\
Dibenzo[a, $h$ ]pyrene & $97.2 \%$ & $87.8 \%$ & $105.6 \%$ \\
\hline & & &
\end{tabular}

$0.25 \mathrm{ng} / \mathrm{cig}$ (ISO) except $\mathrm{B}[a] \mathrm{A}$, chrysene $(0.50 \mathrm{ng} / \mathrm{cig})$ and naphthalene $(25 \mathrm{ng} / \mathrm{cig})$.

\section{CONCLUSIONS}

Yields are consistent with previous studies (19-23). The least abundant PAHs are those with the most rings. This study was able to measure three out of the four 6-ring PAHs at sub-ng/cig levels in the K3R4F. Some 4- and 5ring PAHs were also determined at sub-ng/cig in lower 'tar' products. The matrix is minimalized to such an extent that these detection levels are comfortably attainable. Only one component, $\mathrm{dB}[a l] \mathrm{P}$, was not detected which was due to matrix interference rather than lack of sensitivity. A retention time match $( \pm 1 \mathrm{~s})$ was not achievable for this compound. However, the recovery for this compound in 
the lowest spiked extract (CL2; $0.25 \mathrm{ng} / \mathrm{cig}$ ) was $93 \%$. This method is only concerned with the particulate phase of the smoke aerosol, however, naphthalene has a relatively high vapour pressure $\left(11.6 \mathrm{~Pa} ; 25^{\circ} \mathrm{C}\right)$ making it a semi-volatile compound which will partition between the vapour- and particulate- phases. Therefore, levels of naphthalene in whole smoke would be expected to be higher. The other PAHs on the FDA list have much lower relative vapour pressures $\left(<2.8 \times 10^{-5} \mathrm{~Pa} ; 25^{\circ} \mathrm{C}\right)$ and are found almost entirely in the particulate phase $(21,28)$. We have demonstrated that FDA PAHs can be measured in the smoke condensate using an adapted version of ISO 22634: Determination of $\mathrm{B}[a] \mathrm{P}$ in Cigarette Mainstream Smoke, allowing for continuity from existing regulatory requirements. $\mathrm{B}[a] \mathrm{P}$ is currently the standard marker for overall PAH exposure from tobacco smoke. This method provides the flexibility to be able to determine $\mathrm{B}[a] \mathrm{P}$ and other PAHs if required. Levels of 6-ring and some 4- and 5-ring PAHs were found to be very low; therefore, triplestage quadrupole MS provides a reliable means to see these components without employing complex clean-up procedures.

\section{REFERENCES}

1. Kennaway, E.L. and I. Hieger: Carcinogenic substances and their fluorescence spectra; British Med. J. I (1930) 1044-1046.

2. Cook, J.W., C.L. Hewett, and I. Hieger: The isolation of a cancer-producing hydrocarbon from coal tar; J. Chem. Soc. I, II and III (1933) 395-405.

3. Blacklock, J.W.S.: The production of lung tumours in rats by $3: 4$ benzpyrene, methylcholanthrene and the condensate from cigarette smoke; British J. Canc. 11 (1957) 181-191.

4. Wynder, E. and D. Hoffmann: Tobacco and Tobacco Smoke: Studies in Experimental Carcinogenesis; Academic Press New York and London, 1967.

5. Goldman, R., L. Enewold, E. Pellizzari, J.B. Beach, E.D. Bowman, S.S. Krishnan, and P.G. Shields: Smoking Increases Carcinogenic Polycyclic Aromatic Hydrocarbons in Human Lung Tissue; Canc. Res. 61 (2001) 6367-6371.

6. Rubin, H.: Historical Review, Synergistic mechanisms in carcinogenesis by polycyclic aromatic hydrocarbons and by tobacco smoke: a bio-historical perspective with updates; Carcinogen. 22 (2001) 1903-1930.

7. Thielen, A., H. Klus, and L. Müller: Tobacco smoke: Unraveling a controversial subject; Exp. Tox. Path. 60 (2008) 141-156.

8. United States Public Laws: Stat. 1776: The Family Smoking Prevention and Tobacco Control Act; 2009, available at: http://www.fda.gov/tobaccoproducts (accessed May 01, 2013).

9. Center for Tobacco Products, United States Food and Drug Administration: Guidance for Industry, Reporting Harmful and Potentially Harmful Constituents in Tobacco Products and Tobacco Smoke Under Section 904(a) (3) of the Federal Food, Drug, and Cosmetic Act; 2012; available at: http://www.fda.gov/tobacco guidance (accessed May 01 2013).
10. Irigaray, P., S. Lacomme, L. Mejean, and D. Belpomme: Ex vivo study of incorporation into adipocytes and lipolysis-inhibition effect of polycyclic aromatic hydrocarbons; Tox. Lett. 187 (2009) 35-39.

11. International Organisation for Standardisation (ISO): International Standard ISO 22634: Determination of benzo $[a]$ pyrene in cigarette mainstream smoke method using gas chromatography/mass spectrometry; ISO, Geneva, Switzerland, 2007.

12. de Hoffmann, E.: Tandem mass spectrometry: A primer; J. Mass Spectrom 31 (1996) 129-137.

13. CORESTA Recommended Method No. 58: Determination of benzo $[a]$ pyrene in cigarette mainstream smoke method using gas chromatography/mass spectrometry; 2004 revised 2013, Cooperation Centre for Scientific Research Relative to Tobacco, Paris, France.

14. Personal communication by e-mail (Sept. 29, 2008) from K. Greenwood: Philip Morris International Research and Development: Proficiency Test for Mainstream Smoke Constituents Analysis 2007/2008.

15. Intorp, M., S. Purkis, M. Whittaker, and W. Wright: Determination of "Hoffman Analytes" in Cigarette Mainstream Smoke. The CORESTA 2006 Joint Experiment; Beitr. Tabakforsch. Int. 23 (2009) 161-202.

16. Personal communication by e-mail (Feb. 07, 2013) from G. Jaccard: Philip Morris International Research and Development: Collaborative Test Mainstream Smoke Constituents; Analysis of data collected in October - December 2012; ISO Smoking Regime.

17. International Organisation for Standadarsation (ISO): International Standard ISO 3308: Routine analytical cigarette-smoking machine - Definitions and standard conditions; ISO, Geneva, Switzerland, 2000.

18. Health Canada Method T-115; available at http://www. hc-sc.gc.ca (accessed May 01, 2013).

19. Robb, E.W., G.C. Guvernator, M.D. Edmonds, and A. Bavley: Analysis of Polycyclic Hydrocarbons; Beitr. Tabakforsch. 3 (1965) 278-284.

20. Gmeiner, G., G. Stehlik, and H. Tausch: Determination of seventeen polycyclic aromatic hydrocarbons in tobacco smoke condensate; J. Chromatogr. 767 (1997) 163-169.

21. LGC Report GC15/M09/02: Report commissioned by the UK Department of Health: Comparison of mainstream smoke yields of tar, nicotine, carbon monoxide and polycyclic hydrocarbons from cigarettes and small cigars; 2002, available at: http://legacy.library.ucsf. edu/documentStore/g/q/p/gqp34a00/Sgqp34a00.pdf (accessed June 17, 2013).

22. Rodgman, A. and C.R. Green: Toxic Chemicals in Cigarette Mainstream Smoke - Hazard and Hoopla; Beitr. Tabakforsch. Int. 20 (2003) 481-545.

23. Roemer, E., H. Schramke, H. Weiler, A. Buettner, S. Kausche, S. Weber, A. Berges, M. Stueber, M. Muench, E. Trelles-Sticken, J. Pype, K. Kohlgrueber, H. Voekel, and S. Wittke: Mainstream Smoke Chemistry and In Vitro and In Vivo Toxicity of the Reference Cigarettes 3R4F and 2R4F; Beitr. Tabakforsch. Int. 25 (2012) 316-335.

24. International Organisation for Standadarsation (ISO): International Standard ISO 3402: Tobacco and tobacco 
products - Atmosphere for conditioning and testing; ISO, Geneva, Switzerland, 1999.

25. International Organisation for Standadarsation (ISO): International Standard ISO 4387: Determination of Total and Nicotine-Free Dry Particulate Matter using a Routine Analytical Cigarette Smoking Machine Determination of Total Particulate Matter and Preparation for Water and Nicotine Measurements; ISO, Geneva, Switzerland, 2000.

26. Health Canada Method T-103; available at http://www.hc-sc.gc.ca (accessed May 15, 2013).

27. LGC Report FN40/M26/00: Report commissioned by the UK Department of Health: Comparison of Yields of Benzo $[a]$ pyrene from USA and UK Blend Cigarettes, 2000, available at http://legacy.library.ucsf. edu/tid/mqh17a00/pdf (accessed June 17, 2013).
28. Kalaitzoglou, M. and C. Samara: Distribution of Polycyclic Aromatic Hydrocarbons between the Particulate and the Gas Phase of Mainstream Cigarette Smoke in Relation to Cigarette Technological Characteristics; Beitr. Tabakforsch. Int. 21 (2005) 331-344.

Corresponding author:

William Guthery

Filtrona, Filtrona Technology Centre

Tyne and Wear NE32 3UP, UK

E-mail: billguthery@filtrona.com 